\title{
Occurrence of Meyeria magna M'Coy, 1849 in Colombia: a widely distributed species during Aptian times
}

\author{
Francisco J. Vega ${ }^{1, *}$, Rodney M. Feldmann², Fernando Etayo-Serna ${ }^{3}$, \\ Hermann D. Bermúdez-Aguirre ${ }^{4}$ and Jorge Gómez ${ }^{3}$ \\ ${ }^{1}$ Instituto de Geología, Universidad Nacional Autónoma de México. \\ Ciudad Universitaria. México, D.F., Mexico. \\ ${ }^{2}$ Department of Geology, Kent State University, \\ Kent, Ohio, 44242, USA. \\ ${ }^{3}$ INGEOMINAS-Museo Geológico José Royo y Gómez, \\ Dg 5334-53, Bogota DC, Colombia. \\ ${ }^{4}$ Geostratos Lta. Cra. 40, no. 22C-60, Bloque B3, Apto. 1201, \\ Bogotá DC, Colombia. \\ *vegver@servidor.unam.mx
}

\begin{abstract}
Occurrence of the mecochirid decapod Meyeria magna M'Coy 1849 is documented based on numerous articulated specimens collected from upper Aptian strata of Colombia. This report represents the first record in America for the species, previously reported from Aptian deposits of Europe. The numerous specimens of a relatively uniform size found in a single stratigraphic level suggests a mass mortality event, favorable conditions for the development of the community, or both. The stratigraphic range for the genus Meyeria is confirmed to be Lower to Upper Cretaceous.
\end{abstract}

Key words: Crustacea, Mecochiridae, Meyeria, Aptian, Colombia.

\section{Resumen}

La presencia del decápodo mecoquírido Meyeria magna M'Coy 1849, es documentada con base en numerosos ejemplares articulados, recolectados en estratos del Aptiano superior de Colombia. Este reporte representa el primer registro de esta especie para América, ya que sólo se había reportado de depósitos del Aptiano de Europa. Los numerosos ejemplares, de talla relativamente uniforme, encontrados en un solo nivel estratigráfico, sugieren un evento de mortandad masiva, condiciones favorables para el desarrollo de la comunidad, o ambos escenarios. Se confirma que el rango estratigráfico del género Meyeria corresponde del Cretácico Inferior al Cretácico Superior.

Palabras clave: Crustacea, Mecochiridae, Meyeria, Aptiano, Colombia. 


\section{Introduction}

Twenty-one crustacean specimens of the species Meyeria magna M'Coy 1849, were collected in outcrops near La Quebrada El Cobre, Municipio de Payandé, Departamento de Tolima, about $120 \mathrm{~km}$ southwest of Bogotá, Colombia (Figure 1). The lithologic unit from which the crustaceans were collected is found at Valle Superior del Magdalena Basin, it has not been formally named (Figure 2). The specimens were found approximately $1 \mathrm{~m}$ above a layer that contains the cephalopod species Heminautilus etheringtoni Durham, 1946, Kutatissites cf. boteroi Etayo-Serna, 1979 and Cheloniceras sp. (Figure 3) that indicate a late Aptian age (Etayo-Serna, 1979; 1983), and were collected from a single fossiliferous horizon $0.25 \mathrm{~m}$ thick (Figure 4 ). The specimens are preserved with most appendages articulated, and there is no clear evidence for a separation between the cephalothorax and the abdomen. This mode of preservation suggests that the specimens were corpses. Their numerous occurrences in concretions from a single horizon may indicate a massive mortality event. Based upon comparison of the morphological details, the Colombian specimens are identified as Meyeria magna M'Coy 1849, described from the lower Aptian of England.

Hoploparia colombiana Beurlen, 1938, was described from the Neocomian of Colombia, based on a single, incomplete cephalothorax, but its position suggests that the locality is part of the lower Albian Tablazo Formation (Ulloa and Rodríguez, 1978). That species was attributed to Mecochirus by Förster and von Hillebrandt (1984). The state of preservation of the partial specimen makes it difficult to confirm its systematic affinity.

The studied specimens are deposited in the collection of INGEOMINAS, Museo Geológico José Royo y Gómez, Dg. 53, N. 34-53, Bogotá DC, Colombia, acronym JGT100.

\section{Systematic Paleontology}

Order Decapoda Latreille, 1802

Suborder Pleocyemata Burkenroad, 1963

Infraorder Astacidea Latreille, 1802

Family Mecochiridae Van Straelen, 1924 [imprint 1925]

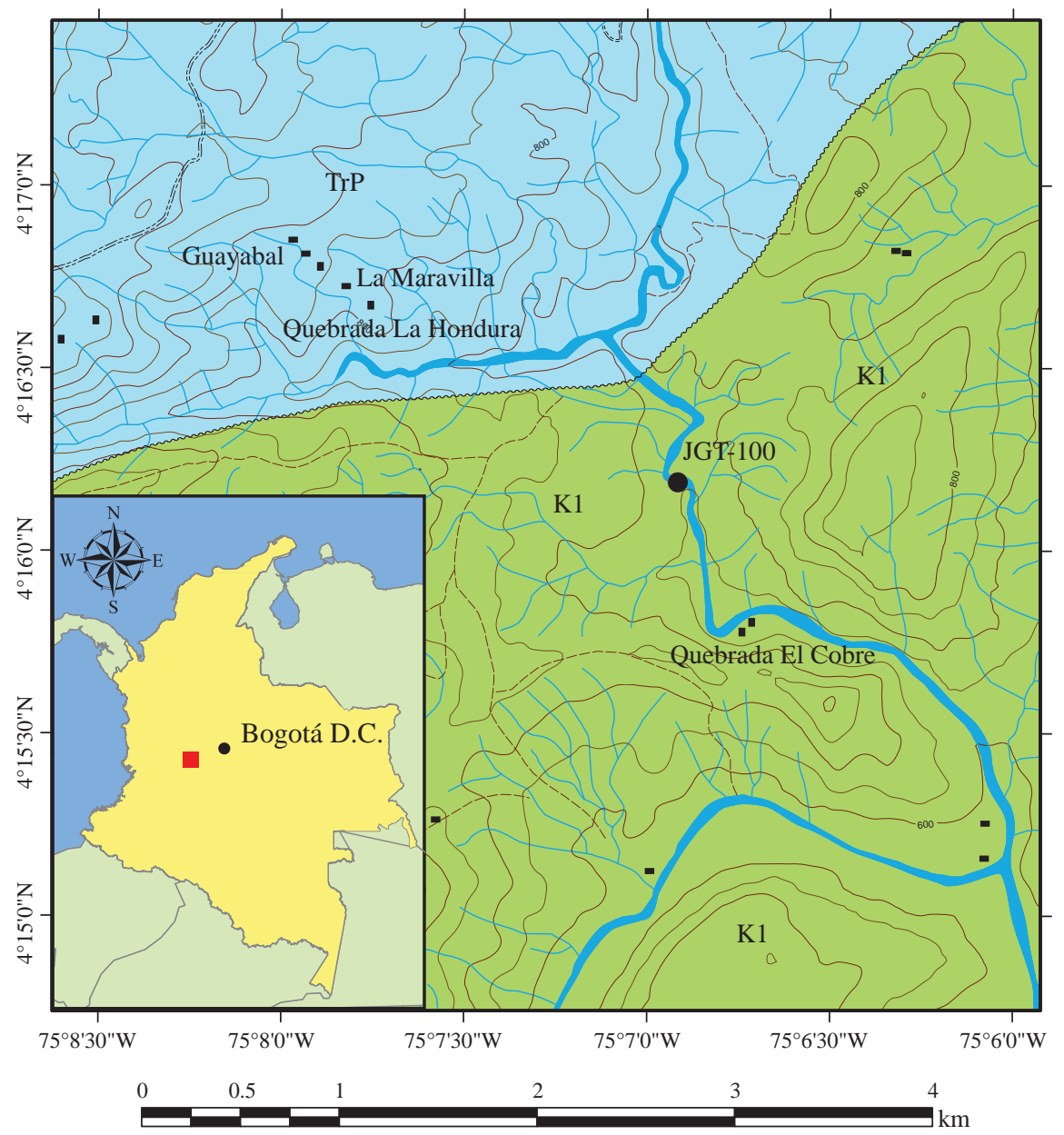

Figure 1. Location map of study area in Colombia, southwest Bogotá, including fossil locality (JGT-100), north of Quebrada El Cobre. Blue area represents Triassic rocks of the Payandé Group (TrP), while green area indicates Lower Cretaceous units (Kl). 
Mecochirus Germar, 1827

Huhatanka Feldmann and West, 1978

Meyeria M'Coy, 1849

?Praeatya Woodward, 1868

Pseudoglyphea Oppel, 1861 (=Triassiglyphea Van

Straelen, 1936)

\section{Genus Meyeria M'Coy 1849}

Type species. Meyeria ornata Phillips, 1829.

Included species. Meyeria crofti Ball, 1960; M. magna M'Coy 1849; M. mexicana Rathbun, 1935; M. ornata Phillips, 1829; M. pueblaensis Feldmann, Vega, GarcíaBarrera, Rico-Montiel, and Martínez-López, 1995; M. rapax Harbort, 1905; M. schwarzi Kitchin, 1908.

\section{Meyeria magna M'Coy 1849}

Figures 5 - 7

Synonymies. Meyeria bolivari Van Straelen, 1927 (fide Förster, 1971); Bataller, 1950; M. pearcei Spence-Bate in Lee, 1881 (fide Woods, 1928); M. vectensis Bell, 1863 (fide Woods, 1928); Oncopareia granulosa Vilanova, 1863; Mallada, 1892; Hoploparia granulosa Via, 1951; Meyeria magna M'Coy 1849; Via, 1975.

Nomina nuda. Meyeria? harveyi Woodward, 1900 (fide Förster, 1971).

Description. Mecochirid of large size; cephalothorax proportionally large, subcylindrical, about two-thirds the length and twice the height of abdomen, with a median dorsal groove extending from posterior margin to level of

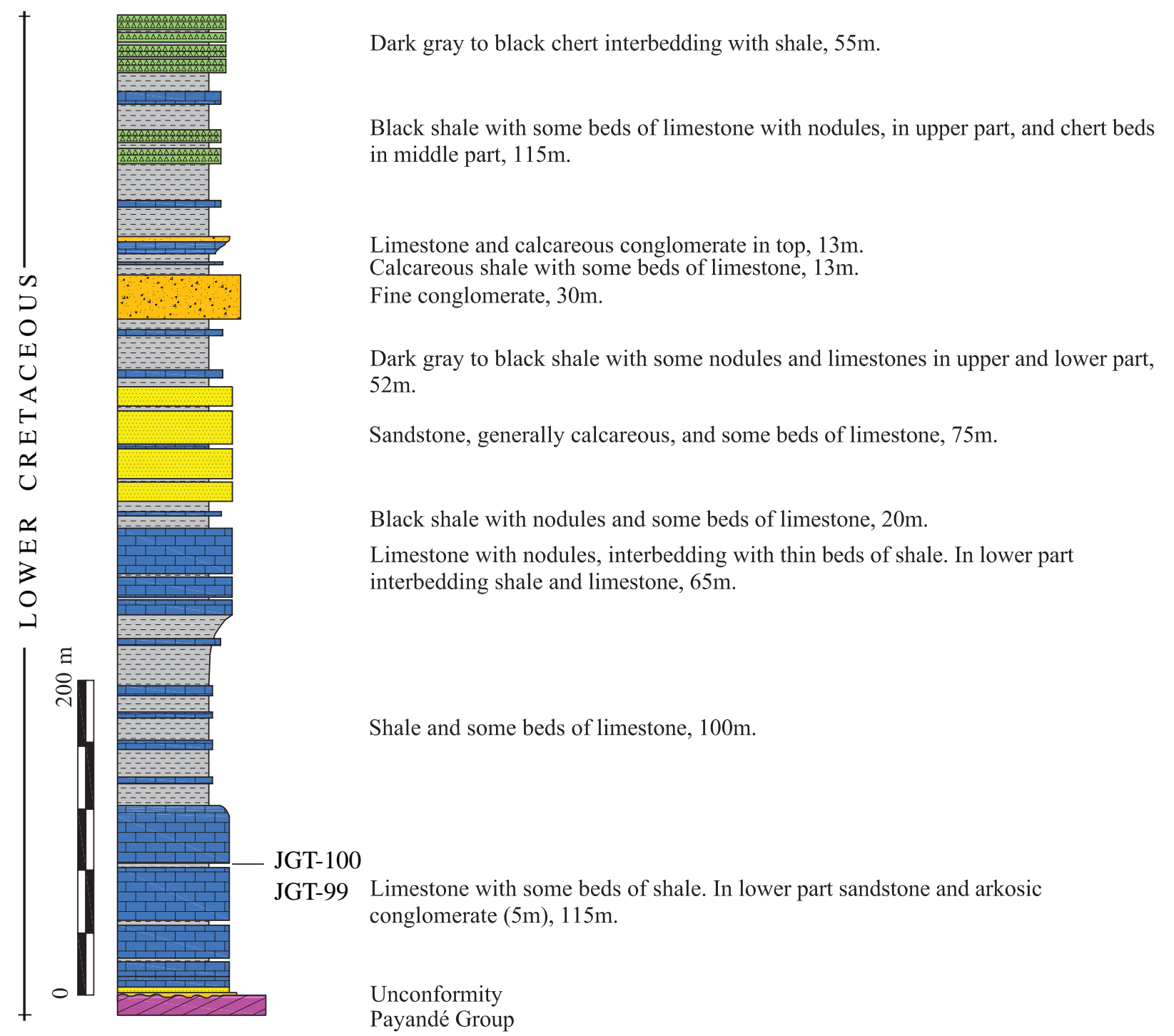

Figure 2. Stratigraphic section at Quebrada El Cobre, showing position of fossil locality (JGT-100) in calcareous beds of late Aptian age. After Barrero, in Julivert (1968). 

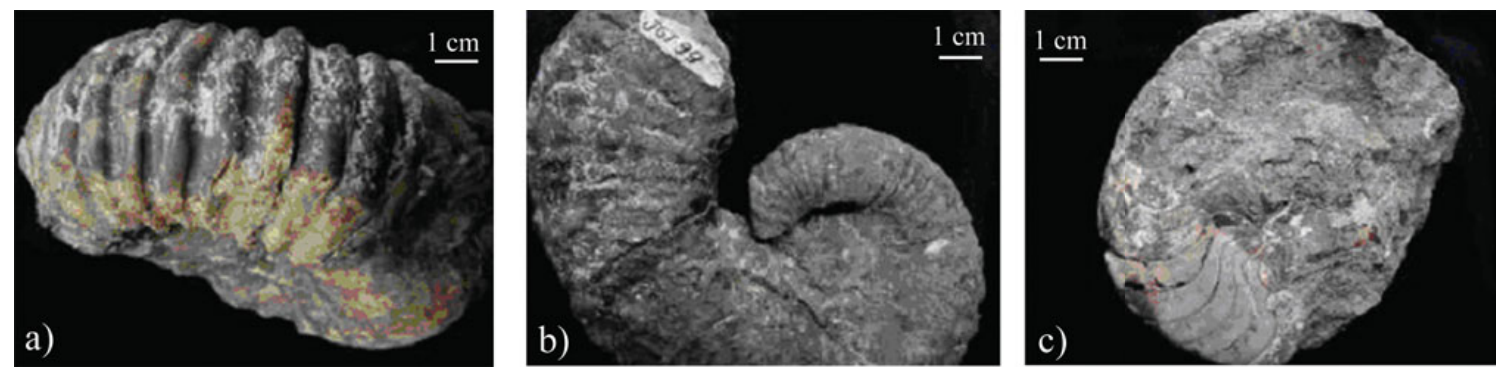

Figure 3. Late Aptian cephalopods associated with crustaceans here reported. a) Cheloniceras sp. b) Kutatissites sp. cf. boteroi Etayo-Serna, 1979. c) Heminautilus etheringtoni Durham, 1946.

cervical groove, delimited laterally by two sharp ridges with granules on the crest; antennal region one-third the cephalothorax length, with three longitudinal ridges, middle and lower ridges are stronger and bear sharp, forward-directed spines, spaces between ridges are smooth; cervical groove deep, two-thirds the height of cephalothorax, inclined toward lower anterior margin; branchiocardiac groove shallow, slightly inclined from the upper part of posterior margin to mid-height of carapace; postcervical groove very shallow and parallel to branchiocardiac groove; hepatic groove shallow and curved upward at distal end, surrounds subcircular hepatic lobe; another subovate lobe lies above hepatic lobe; a ridge at the level of median ridge of anterior region extends from cervical groove backwards to reach branchocardiac groove; anterior cardiac region with a few small tubercles; branchial area covered by evenly-spaced small tubercles of uniform size, becoming more numerous toward ventral margin and hepatic lobe; a marginal rim and shallow groove mark posterior part of cephalothorax; small rim marks ventral margin.
Abdomen plus telson one third longer than cephalothorax; abdominal segments with six longitudinal rows of tubercles, three on each side, row of tubercles at contact with pleura the strongest; first abdominal somite short, segment triangular in lateral view; second abdominal segment twice the length of first segment, pleura subrectangular, anterior and lower margins rounded, posterior margin straight, longitudinal ridge on middle portion and a strong boss near lower margin; second to fifth abdominal segments of similar shape and size, with triangular terga and middle longitudinal ridge, as well as prominent boss in lower portion of terga; sixth abdominal segment triangular in longitudinal view, pleura triangular, strong ridge at contact with tergum; telson longitudinally rectangular, with a median groove, basis subovate, smooth; endopodite and exopodite triangular, proximal two-thirds covered by fine granules, rounded lower margin, both with median keel, diaeresis present.

First pereiopod long, two-thirds the total length of carapace; ischium subtriangular; merus rectangular, four

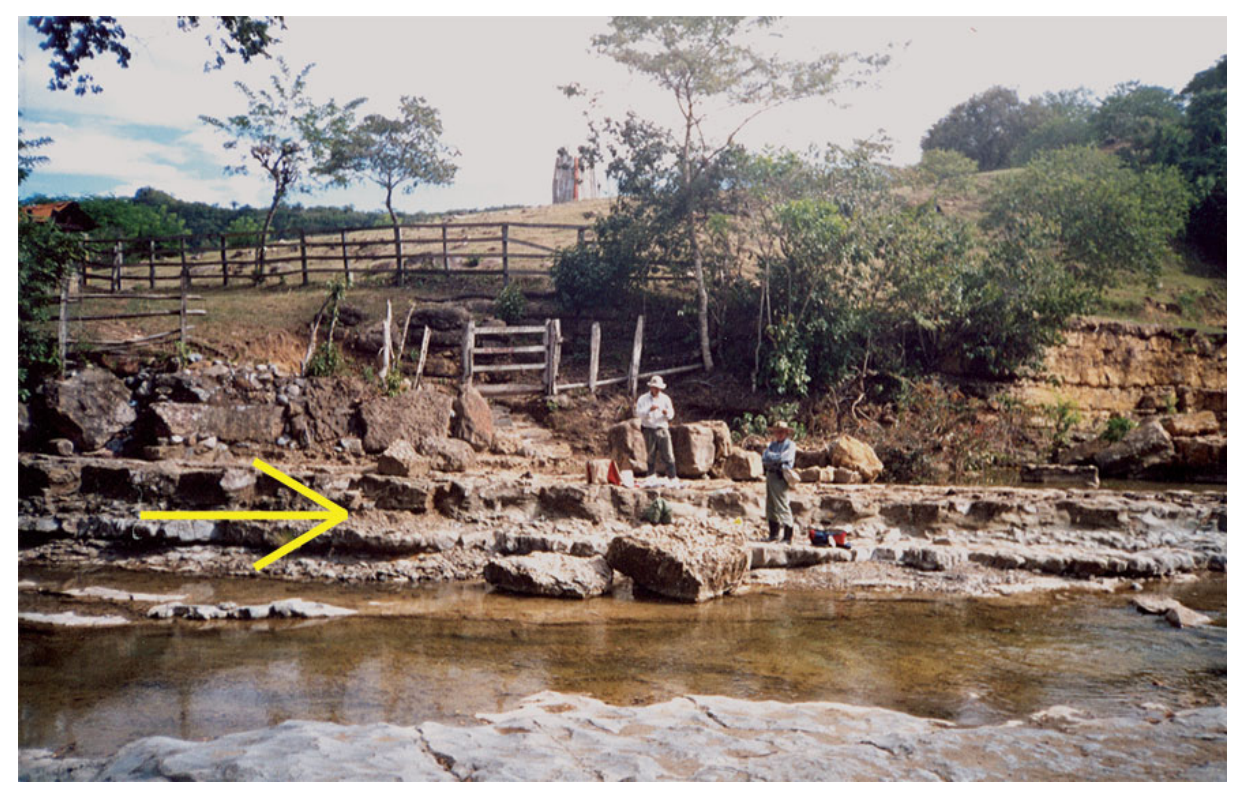

Figure 4. Locality JGT-100, arrow indicates fossiliferous horizon. 

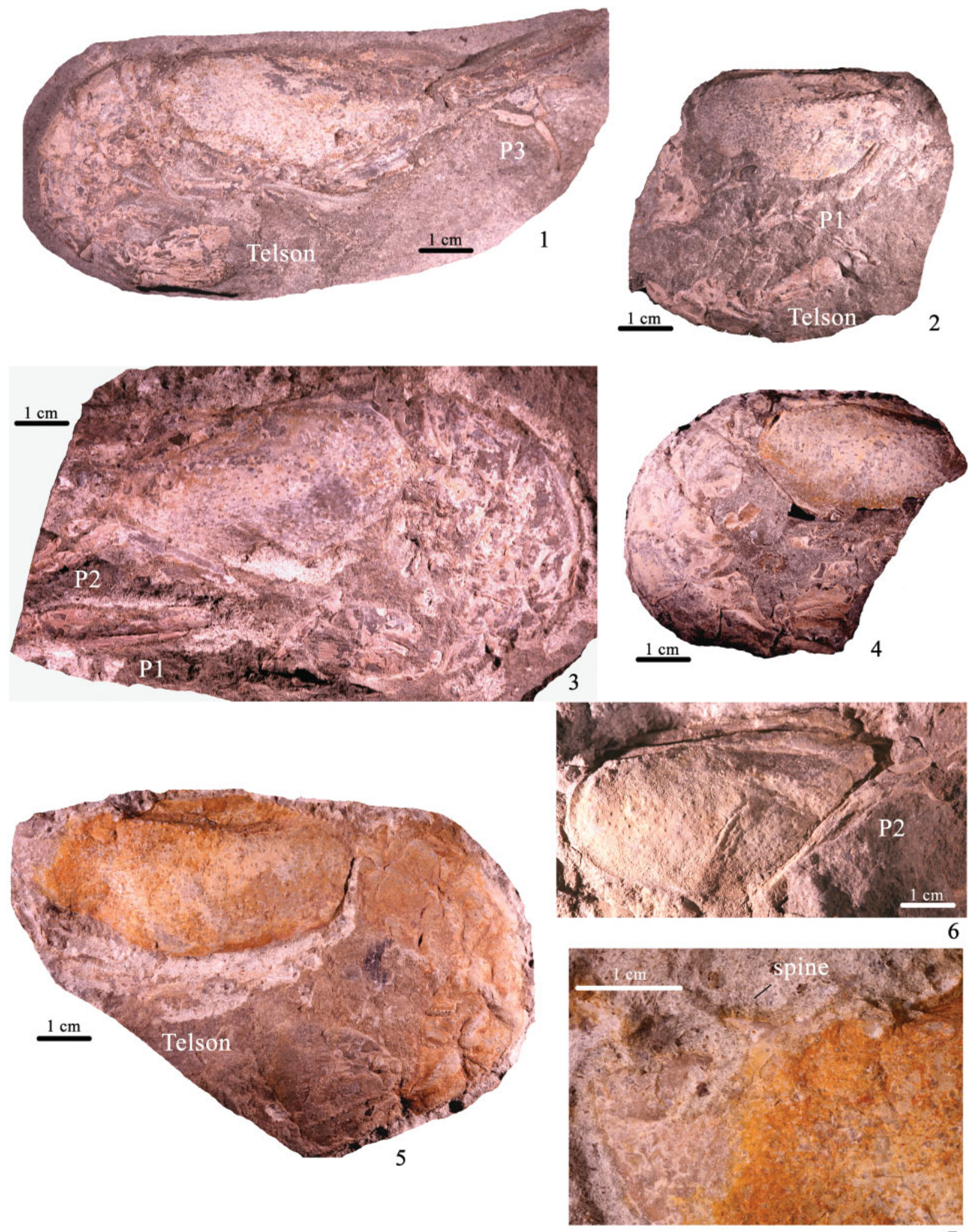

Figure 5. Meyeria magna M'Coy 1849, upper Aptian, Quebrada El Cobre, Colombia. 1: Nearly complete specimen, showing third pereiopod and telson, hypotype JGT-100/01. 2: Specimen showing cephalothorax, first pereiopod (P1) and telson, hypotype JGT-100/06. 3: Nearly complete specimen, showing first and second pereiopods (P1, P2), hypotype JGT-100/11. 4: Incomplete specimen showing partial cephalothorax and abdomen, hypotype JGT-100/07. 5: Specimen showing cephalothorax, abdomen and telson, hypotype JGT-100/20. 6: Cephalothorax and second pereiopods (P2), hypotype JGT-100/03. 7: Posterior spine of middle ridge in antennal region, hypotype JGT-100/20. 

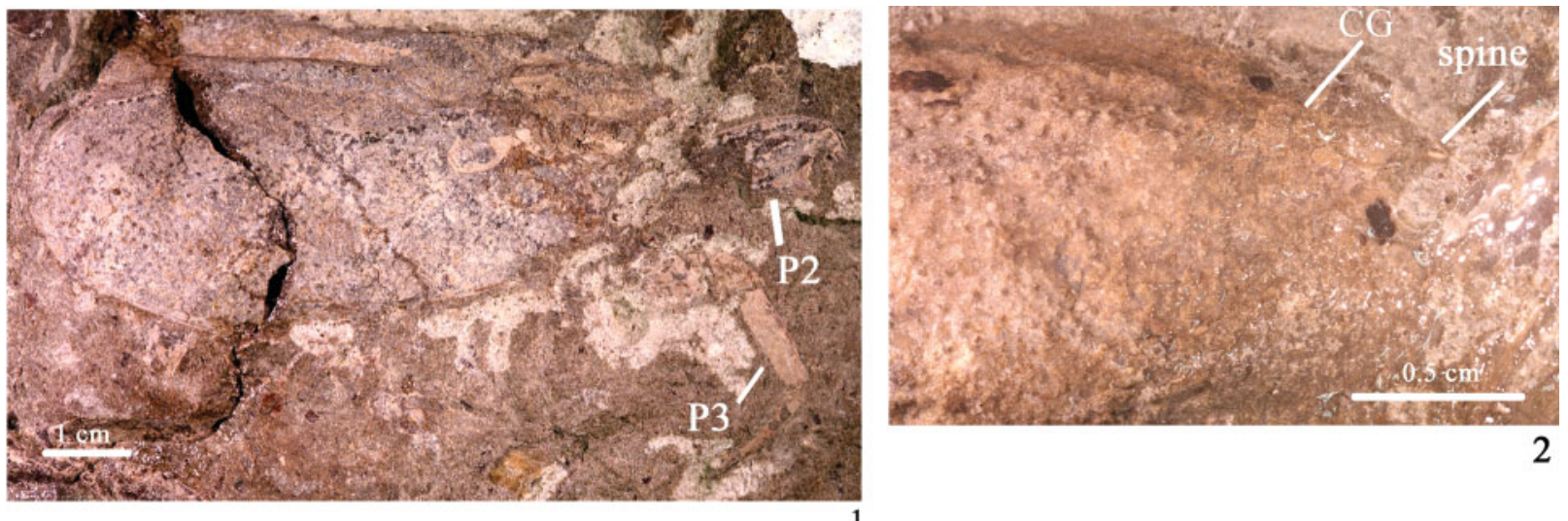

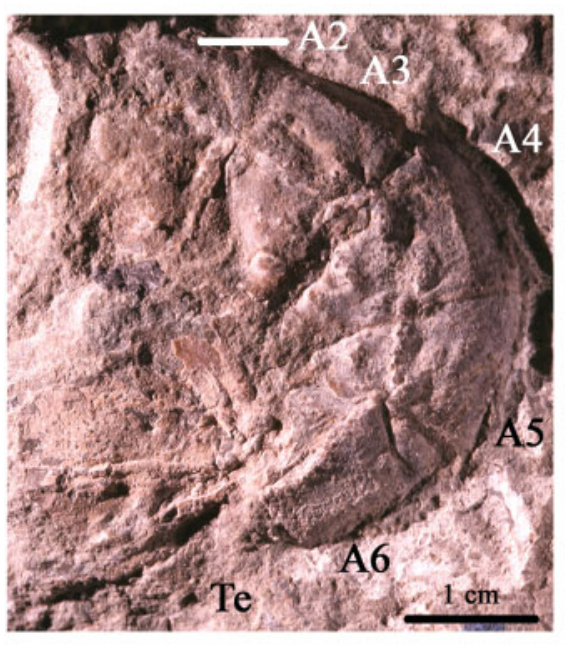

3
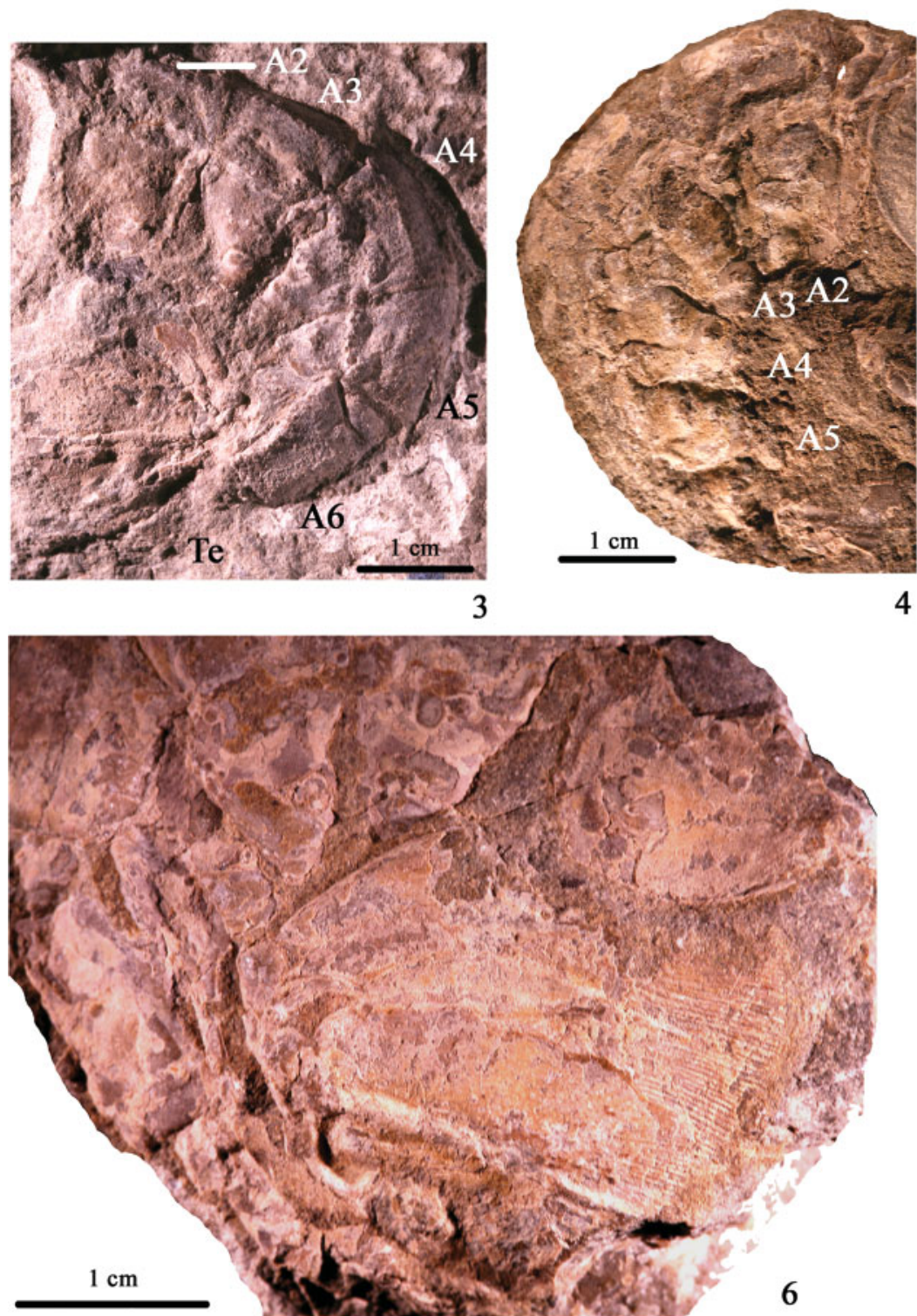

4
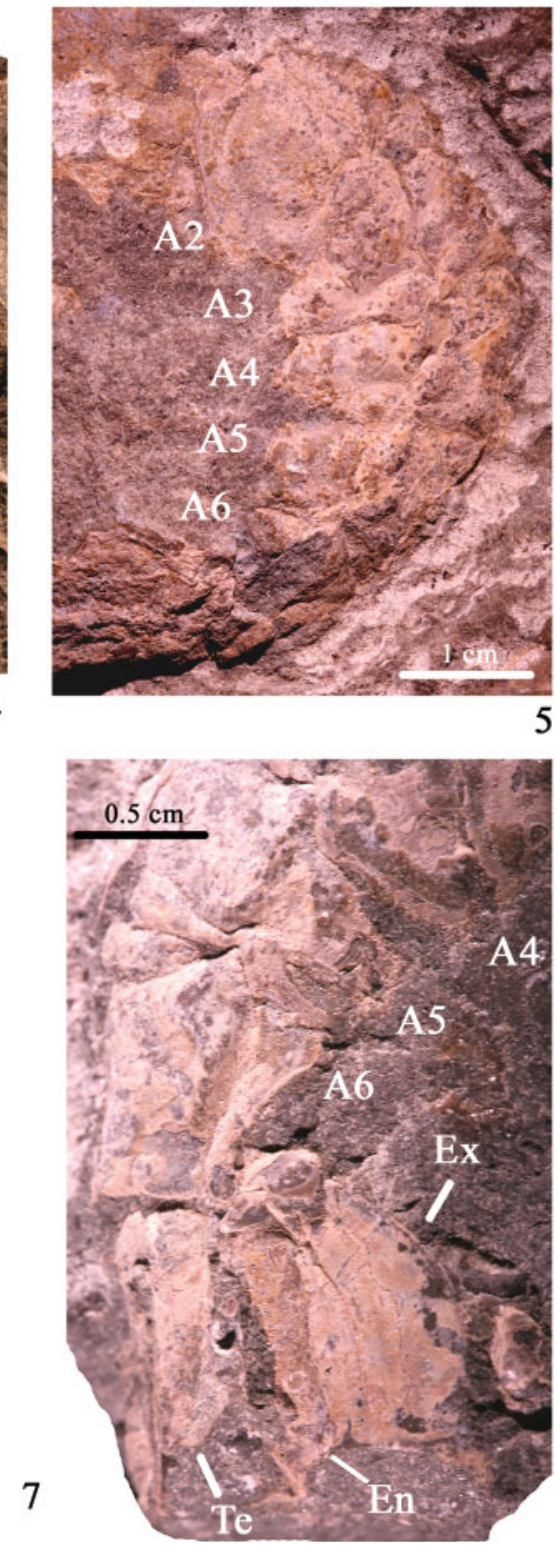

Figure 6. Meyeria magna M'Coy 1849, upper Aptian, Quebrada El Cobre, Colombia. 1: Cephalothorax with subchelate second pereiopod (P2), and third pereiopod (P3), hypotype JGT-100/13. 2: Posterior spine of middle ridge in antennal region, CG = cervical groove, hypotype JGT-100/18. 3: Specimen showing second to sixth abdominal somites (A2 - A6) and telson, hypotype JGT-100/09. 4: Specimen showing second to fifth abdominal somites (A2 - A5), hypotype JGT-100/08. 5: Specimen showing second to sixth abdominal somites (A2 - A6), hypotype JGT-100/02. 6: Detail of telson, endopodite and exopodite, hypotype JGT-100/17. 7: Detail of fourth to sixth abdominal somites (A4 - A6), telson (Te), endopodite (En) and exopodite (Ex), hypotype JGT-100/07. 

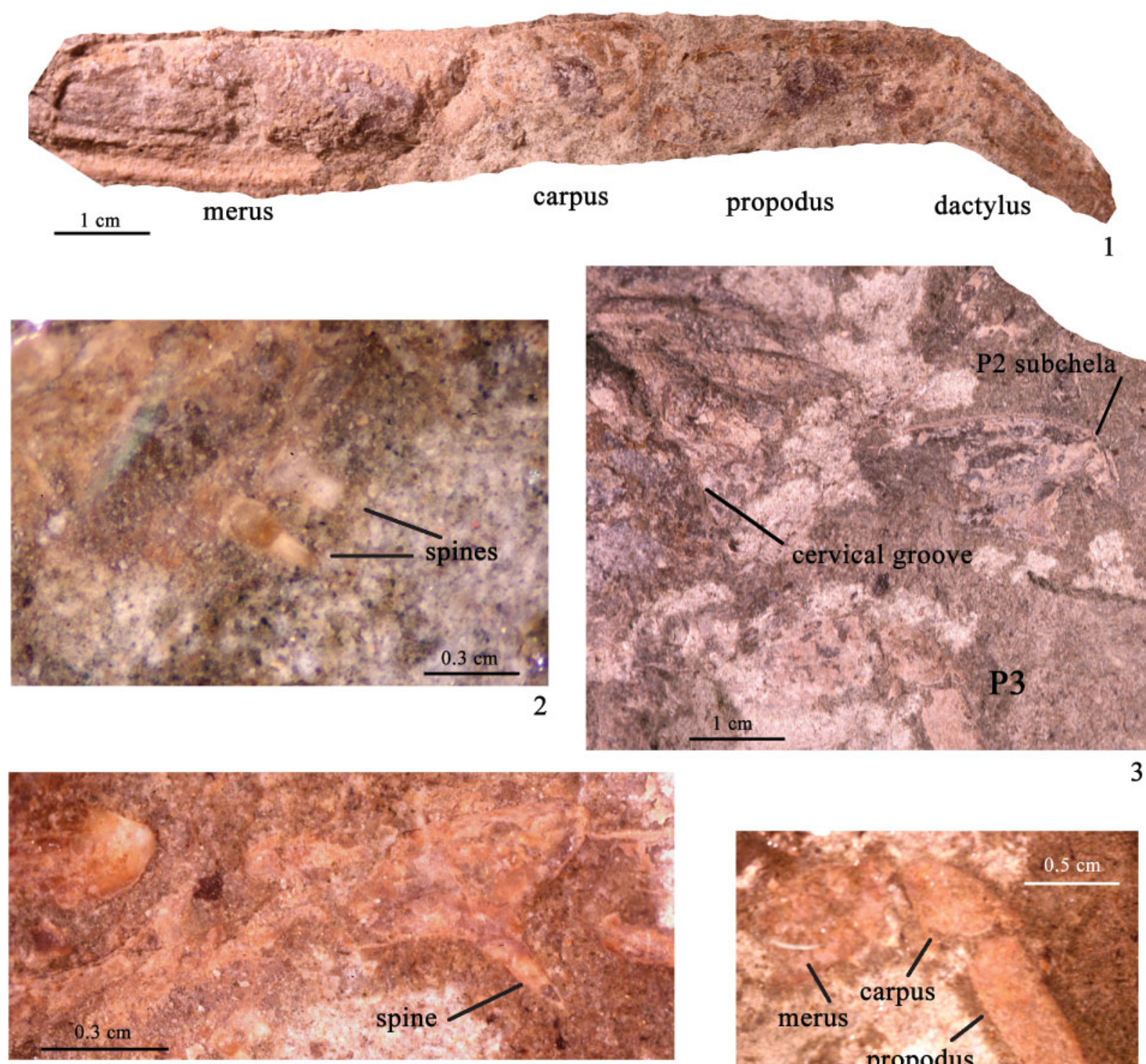

4
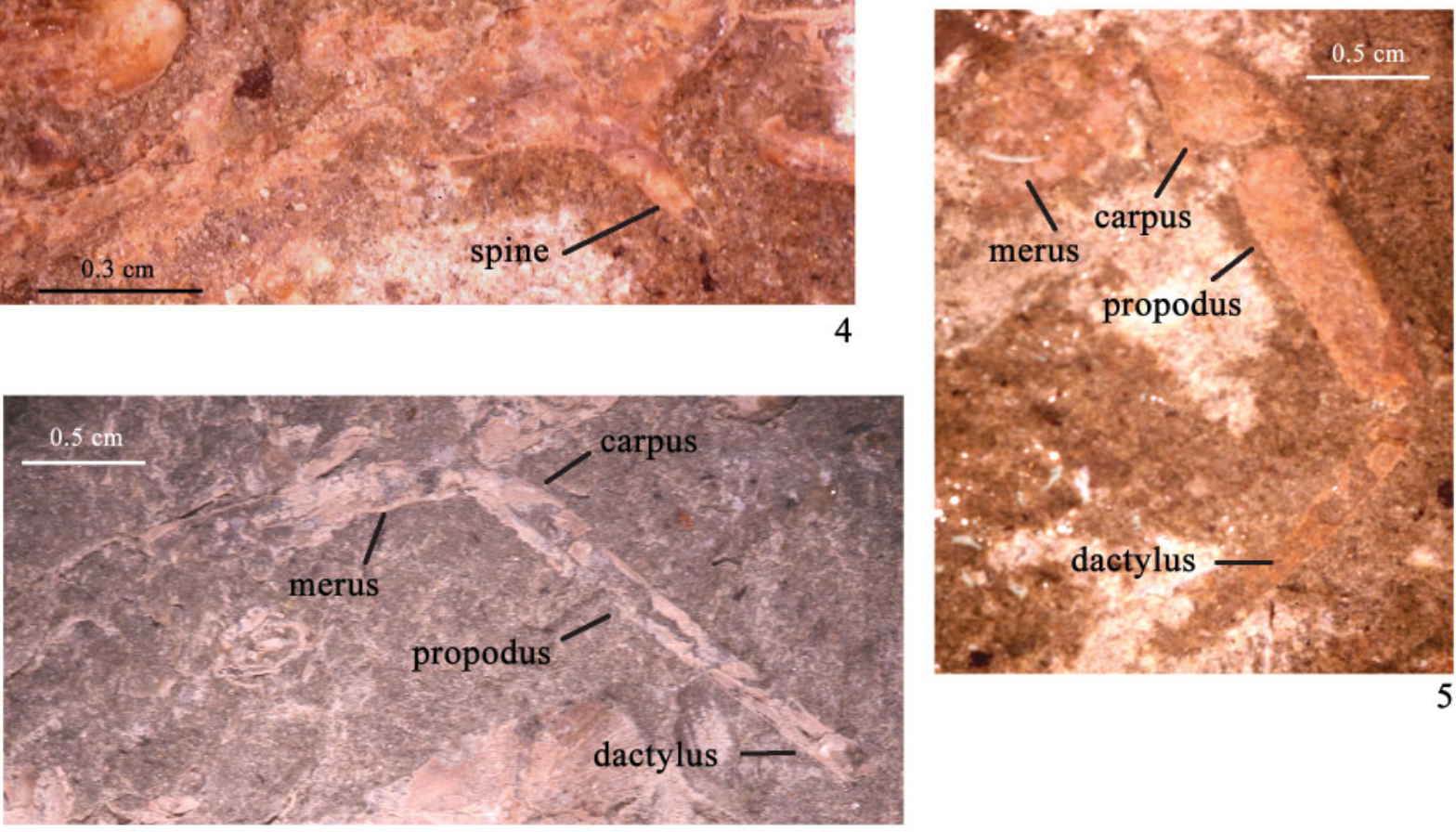

Figure 7. Meyeria magna M'Coy 1849, upper Aptian, Quebrada El Cobre, Colombia. 1: Right first pereiopod showing distal articles, hypotype JGT100/21. 2: Detail of spines on the lower margin of merus of first pereiopod, hypotype JGT-100/21. 3: Anterior portion of cephalothorax, showing cervical groove, ridges of antennal region, subchela of second pereiopod and third pereiopod (P3), hypotype JGT-100/21. 4: Detail of spine at the distal lower margin of carpus of first pereiopod, hypotype JGT-100/21. 5: Detail of articles of third pereiopod, hypotype JGT-100/13. 6: Detail of articles of fourth pereiopod, hypotype JGT-100/06. 
times longer than ischium, lower margin with keel and three sharp spines on distal portion; carpus subtrapezoidal, one-fourth merus length, with long, sharp spine on lower anterior margin; propodus subrectangular, half the length of merus, narrow at junction with dactylus; dactylus pointed, one-third the length of merus, half the height of propodus. Second pereiopod subchelate, merus rectangular, elongate, lower margin with keel; carpus subquadrate, slightly wider at junction with propodus; propodus subquadrate, flat; dactylus unciform, articulated to upper part of propodus. Third pereiopod, two-thirds the length and half the height of first pereiopod; merus rectangular elongate; carpus subtrapezoidal; propodus rectangular, twice the length of carpus; dactylus unciform, two-thirds the propodus length and two-thirds its height. Fourth and fifth pereiopods slender, about one-third the length of first pereiopod. Ischium of fourth pereiopod subtriangular; merus rectangular, elongate, five times the length of ischium; carpus subtrapezoidal, one-third the merus length; propodus rectangular, four times carpus length; dactylus unciform, two-thirds the length of propodus.

Material. Twenty-one specimens, hypotypes JGT-100/01 to JGT-100/21, upper Aptian, La Quebrada El Cobre, Municipio de Payandé, Departamento del Tolima, about 120 km southwest of Bogotá.

Measurements. Measurements of specimens are given in Table 1.
Discussion. The synonymy of Mecochirus Germar, 1827, and Meyeria M'Coy 1849 was suggested by Förster (1971), but important differences between these two mecochirid genera have been noted (Herrick and Schram, 1978; Feldmann et al., 1995). According to Aguirre-Urreta (1989), Meyeria rapax Harbort, 1905, from the Valanginian-Hauterivian (Lower Cretaceous) of Argentina differs from M. magna in having a weaker ornamentation of the carapace, different shape of abdominal terga, and stronger inferior and postcervical grooves. The type species, Meyeria ornata (Phillips, 1829) from the Lower Cretaceous (Neocomian) of England, Switzerland, and Germany (Glaessner, 1929), has strong, beaded transverse ridges on the abdominal terga. Another species of Meyeria from the southern hemisphere (Feldmann and Schweitzer, 2006) is M. schwarzi Kitchin, 1908, from the Neocomian of South Africa. It resembles $M$. rapax, but it is smaller and has a more compressed cephalothorax. A review of the holotype of $M$. mexicana Rathbun, 1935, from the upper Aptian of Chihuahua, Mexico, revealed important morphological similarities to M. magna, and was considered to be in synonymy with the European species (Simpson and Middleton, 1985); however, there are sufficient differences between the two species to maintain them as distinct. The cephalic ridges on Meyeria magna are granular, but those on $M$. mexicana are smooth. The branchial region of $M$. magna is granular on the dorsal surface, whereas it is smooth on M. mexicana. Finally, the branchiocardiac groove on M. magna crosses the branchial region in a convex-up arc, whereas that of $M$.

Table 1. Measurements (in mm) of Meyeria magna specimens from Colombia, including cephalothorax (Ceph.) and abdomen (Abd.) length and height.

\begin{tabular}{|c|c|c|c|c|}
\hline Hypotype & Ceph. length & Ceph. height & Abd. length & Abd. height \\
\hline JGT-100/01 & 47.5 & 23.2 & 64.0 & 20.5 \\
\hline JGT-100/02 & ---- & ---- & 85.6 & 18.1 \\
\hline JGT-100/03 & 39.3 & 22.6 & ---- & ---- \\
\hline JGT-100/04 & 47.1 & 24.2 & 73.2 & 15.5 \\
\hline JGT-100/05 & 53.4 & 26.7 & 91.8 & 22.2 \\
\hline JGT-100/06 & ---- & --- & 46.9 & 24.5 \\
\hline JGT-100/07 & ---- & ---- & 89.0 & 19.8 \\
\hline JGT-100/08 & 52.4 & 23.0 & 66.5 & 19.1 \\
\hline JGT-100/09 & 40.5 & 18.9 & 86.7 & 18.1 \\
\hline JGT-100/10 & 34.4 & 16.3 & 60.2 & 19.5 \\
\hline JGT-100/11 & 39.9 & 23.7 & 65.0 & 23.2 \\
\hline JGT-100/12 & 46.4 & 21.8 & ---- & ---- \\
\hline JGT-100/13 & 61 & 34.2 & ---- & ---- \\
\hline JGT-100/14 & 40.9 & 20.7 & ---- & ---- \\
\hline JGT-100/15 & 45.6 & 21.5 & 52.2 & 16.1 \\
\hline JGT-100/16 & 41.9 & 24.0 & 77.9 & 19.0 \\
\hline JGT-100/17 & ---- & ---- & 117.3 & 23.5 \\
\hline JGT-100/18 & 55.2 & 24.4 & 83.5 & 20.4 \\
\hline JGT-100/19 & 45.0 & 15.9 & 54.7 & 18.2 \\
\hline JGT-100/20 & 57.3 & 27.1 & 86.5 & 21.4 \\
\hline JGT-100/21 & 57.7 & 29.3 & 55.0 & 16.2 \\
\hline
\end{tabular}


Table 2. List of species of Meyeria considered in this work, including their geographic and stratigraphic occurrence.

\begin{tabular}{lccc}
\hline Species & Locality & Age & Current status \\
\hline Meyeria rapax & England, Germany, Argentina & Valanginian-Hauterivian & Meyeria rapax \\
Meyeria ornatus & England, Germany,Switzerland & Neocomian & Meyeria ornata \\
Meyeria schwarzi & South Africa & Neocomian & Meyeria schwarzi \\
Meyeria magna & England & Aptian & Meyeria magna \\
Meyeria bolivari & Spain & Aptian & Meyeria magna \\
Meyeria mexicana & Mexico & Aptian & Meyeria magna \\
Meyeria pueblaensis & Mexico & Aptian & Meyeria pueblaensis \\
Meyeria crofti & Antarctica & Campanian & Meyeria crofti \\
\hline
\end{tabular}

mexicana is nearly straight. Feldmann et al. (1995) described Meyeria pueblaensis Feldmann, Vega, García-Barrera, Rico-Montiel, and Martínez-López, 1995, from the Aptian San Juan Raya Formation, Puebla, Mexico. That species is much smaller than M. magna, has a less ornamented cephalothorax, lacks a beaded ridge along the postcervical groove, and has weaker ornamentation of the abdomen. The abdominal terga are different in shape from M. magna, and the species exhibits sexual dimorphism, according to a recent review of this species (Feldmann et al., 2007). The long first pereiopods of M. pueblaensis are proportionally much thinner than the ones observed in the specimens of M. magna from Colombia. Meyeria bolivari van Straelen, 1927, from the Aptian of Spain, was considered by Förster (1971) to be similar to M. magna, a position supported by Via (1975; 1988; Solé and Via, 1988), who suggested that M. bolivari was a junior synonym of M. magna. Description of M. crofti Ball, 1960, from the Campanian of Antarctica, was based on a single, incomplete cephalothorax fragment. "Meyeria" sp. from the Valanginian of Japan (Koseki et al., 1991) was not published formally (Karasawa et al., 2006), and is represented by a very small specimen. Its systematic position as Meyeria is doubtful (H. Kato, pers. comm.). A list of species of Meyeria, as well as their stratigraphic and geographic distribution is presented in Table 2.

Recently, Astrop (2007) conducted a morphometric and phylogenetic examination of the Mecochiridae employing 12 species, 10 of which were assigned to genera within the family, Mecochirus, Meyeria, and Pseudoglyphea. Glyphea rostrata was also included in the study and Eryma was designated as the outgroup for phylogenetic analysis. From the standpoint of the present study, it was concluded that Meyeria and Mecochirus grouped together but that Meyeria was paraphyletic. The study must be considered preliminary because not all the taxa within the Mecochiridae, as currently defined, were included in the study. However, there are implications for the present study because the type species of Meyeria, M. ornata (Phillips, 1829) did not nest with the other three species included, M. rapax, M. magna, and M. pueblaensis. If this conclusion is borne out by additional work, it would suggest that the latter three species should be assigned to a new genus. However, until this conclusion is further tested, we will continue to consider these species as members of the genus Meyeria.

\section{Paleobiogeography}

The genus Meyeria had a wide distribution during Early Cretaceous times. Its occurrence in the southern hemisphere includes species from the Valanginian and Aptian. Distribution of Meyeria magna during Aptian times include Europe, Mexico, and Colombia. A similar distribution pattern is found for the primitive brachyuran Cenomanocarcinus vanstraeleni Stenzel, 1945 during late Cenomanian and early Turonian times, with occurrences in Germany, Texas, Northeastern Mexico and Colombia (Vega et al., 2007).

\section{Acknowledgments}

The original manuscript was reviewed by G. Schweigert, Staatliches Museum für Naturkunde Stuttgart, Germany, and A. Garassino, Natural History Museum in Milan, Italy, who suggested important ideas to improve the manuscript. Our sincere gratitude to S. Butts, Collections Manager, Peabody Museum, for her support providing images of specimens for comparison. Pedro Artal (Museo Geológico del Seminario de Barcelona) kindly provided bibliographic references and images of specimens from Spain.

\section{Bibliographic references}

Aguirre-Urreta, M.B., 1989, The Cretaceous decapod Crustacea of Argentina and the Antarctic Peninsula: Palaeontology, 32, 3, 499-552.

Astrop, T., 2007, The Family Mecochiridae (Crustacea: Decapoda), a contemporary phylogenetic and morphometric analysis: MS thesis, University of London, 49 p.

Ball, H.W., 1960, Upper Cretaceous Decapoda and Serpulida from James Ross Island, Graham Land: Falkland Islands Dependencies Survey, Scientific Reports, 24, 1-30.

Bataller, J.R., 1950, Sinopsis de las especies nuevas del Cretácico de España. Pars IX, Arthropoda: Anales de la Escuela de Agricultura, Barcelona, 9, 418-428.

Bell, T., 1863, A monograph of the fossil maacostracous Crustacea of Great Britain. Part II. Crustacea of the Gault and Greensand: Palaeontographical Society, London, $21 \mathrm{p}$.

Beurlen, K., 1938, Algunos fósiles cretácicos (vermes, equínidos, crustáceos) de la Cordillera Oriental: Estudios geológicos y paleontológicos de la Cordillera Oriental de Colombia, 128-136, Bogotá. 
Burkenroad, M.D., 1963, The evolution of the Eucarida (Crustacea, Eumalacostraca), in relation to the fossil record: Tulane Studies in Geology, 2: 3-17.

Durham, J.W., 1946, Upper Aptian nautiloids from Colombia: Journal of Paleontology, 20, 5, 428-434.

Etayo-Serna, F., 1979, Zonation of the Cretaceous of Central Colombia by ammonites: Publicaciones Geológicas Especiales de Ingeominas, 2, 1-186.

Etayo-Serna, F., 1983, Georgian heteromorph ammonite genera Kutatissites and Pseudoaustraliceras in Nothwest Southamerica: Geología Norandina, 7, 1-13.

Feldmann, R.M., Schweitzer, C.E., 2006, Paleobiogeography of Southern Hemisphere Decapod Crustacea: Journal of Paleontology, 80, 1, 83-103.

Feldmann, R.M., West, R.R., 1978, Huhatanka, a new genus of lobster (Decapoda: Mecochiridae) from the Kiowa Formation (Cretaceous: Albian) of Kansas: Journal of Paleontology, 52, 6, 1219-1226.

Feldmann, R.M., Vega, F.J., García-Barrera, P., Rico-Montiel, R., Martínez-López, L., 1995, A new species of Meyeria (Decapoda: Mecochiridae) from the San Juan Raya Formation (Aptian: Cretaceous), Puebla State, México: Journal of Paleontology, 69 2, 402-406.

Feldmann, R.M., Vega, F.J., Martínez-López, L., González-Rodríguez, K.A., González-León, O., Fernández-Barajas, R.M., 2007, Crustacea from the Muhi Quarry (Albian - Cenomanian), and a review of Aptian Mecochiridae (Astacidea) from México: Annals of Carnegie Museum, 76, 4, 135-144.

Förster, R., 1971, Die Mecochiridae, eine spezialisierte Familie der mesozoischen Glypheoidea (Crustacea: Decapoda): Neues Jahrbuch für Geologie und Palaeontologie, Abhandlungen, 137, 396-421.

Förster, R., Hillebrandt, A. von, 1984, Das Kimmeridge des Profeta-Jura in Nordchile mit einer Mecochirus-Favreina-Vergesellschaftung (Crustacea, Decapoda - Ichnogenus): Mitteilungen der Bayerischen Staatssammlung für Paläontologie und historische Geologie, 24 67-84.

Germar, E.F., 1827, Ueber die Versteinerungen von Solnhofen. In: Keferstein, C. (ed.): Teutschland geognostisch-geologisch dargestellt und mit Charten und Zeichnungen erläutert, 4, 89-110.

Glaessner, M.F., 1929, Crustacea Decapoda, Part 41, p. 1-141: In J.F. Pompeckj (ed.), Fossilium Catalogus I: Animalia. W. Junk, Berlin.

Harbort, E., 1905, Die Fauna der Schaumburg-Lippeschen Kreidemulde: Abhandlungen der Preussischen Geologischen Landesanstalt, neue Folge. 14, 10-22.

Herrick, E.M., Schram, F., 1978, Malacostracan Crustacean Fauna from the Sundance Formation (Jurassic) of Wyoming: American Museum Novitates, 2652, 1-12.

Julivert, M., 1968, Lexique Stratigraphique International. Amerique Latine, Colombie (premiere partie) - Precambrien, Paleozoique, Mesozoique et intrusions d'age Mesozoique-Tertiaire : Centre National de la Recherche Scientifique, France, 5, 4a, 1-651.

Karasawa, H., Kato, H., Kazunobu, T., 2006, A new member of the Family Prospidae (Crustacea: Decapoda: Brachyura) from the Lower Cretaceous of Japan: Revista Mexicana de Ciencias Geológicas, 23, 3, 344-349.

Kitchin, F.L., 1908, The invertebrate fauna and palaeontological relations of the Uitenhage Series: Annals of The South African Museum, 7, 212-268.

Koseki, O., Tamada, T., Hanamatsu, S., Koide, S., Suzuki, Y., 1991, Fossil lobster from the Lower Cretaceous of Ajishima Island, Ojika-sho, Miyagi Perfecture (in Japanese): Annual Meeting of the Paleontological Society of Japan, Abstracts, p. 98.

Latreille, P.A., 1802-1803, Histoire naturelle, general et particuliére des crustacés et des insectes: Volume 3. F. Dufart, Pars, 468 p.

Lee, J.L., 1881, Notebook of an Amateur Geologist: Longmans Green, London, 90 pp, 209 pls.
Mallada, L., 1892, Catálogo general de las especies fósiles encontradas en España: Boletín de la Comisión del Mapa Geológico de España, $18,1-253$.

M'Coy F., 1849, On the classification of some British fossil Crustacea with notices of new forms in the University Collection at Cambridge: Annals and Magazine of Natural History, series 2, 4, 161-179.

Oppel, A., 1861, Die Arten der Gattungen Glyphea und Pseudoglyphea: Jahreshefte des Vereins für vaterländische Naturkunde in Württemberg, 17, 108-111.

Phillips, J., 1829, Illustrations of the geology of Yorkshire, Part 1. The Yorkshire coast: John Murray, London, 184 p.

Rathbun, M.J., 1935, Fossil Crustacea of the Atlantic and Gulf Coastal Plain: Geological Society of America, Special Paper, 2, 1-160.

Simpson, M.I., Middleton, R., 1985, Gross morphology of the mode of life of two species of lobster from the Lower Cretaceous of England: Meyeria ornata (Phillips) and Meyerella magna (M'coy): Transactions of the Royal Society of Edinburgh, 76, 203-215.

Solé, J., Via, L., 1988, Crusacis Dècapodes fòssils dels Països Catalans (Recopilació i actualizació de dades des 1855 a 1988): Batalleria, 2, 23-42.

Stenzel, H.B., 1945, Decapod crustaceans from the Cretaceous of Texas: University of Texas, Special Publication 4401, 401-476.

Straelen, V. van, 1925, Contribution à l'étude des crustacés décapodes de la période Jurassique : Memoires Academie royale Belgique, Classe des Sciences, Part 4, Séries 2, 7, 1-462.

Straelen, V. van, 1927, Contribution à l'étude des Crustacés Décapodes de la Péninsule Ibérique : Eos, Madrid, 3, 69-79.

Straelen, V. van, 1936, Crustacés décapodes noveaux ou peu connus de l'époque crétacique: Bulletin du Museum royale de Histoire naturelle de Belgique, 12, 45, 1-50.

Ulloa, C.E., Rodríguez, E., 1978, Mapa Geológico preliminar Plancha 170, Vélez. Escala 1: 100.000. INGEOMINAS. Bogotá, Colombia.

Vega, F.J., Nyborg, T.G., Rojas-Briceño, A., Patarroyo, P., Luque, J., Porras-Múzquiz, H., Stinnesbeck, W., 2007, Upper Cretaceous Crustacea from Mexico and Colombia: similar faunas and environments during Turonian times: Revista Mexicna de Ciencias Geológicas, 24, 3.

Via, L., 1951, Contribución al estudio de los decápodos del secundario de España: Anales de la Escuela de Peritos Agrìcolas de España, $10,151-180$

Via, L., 1975, Contribución al estudio de “Mecochirus magnus" (M'coy), crustáceo decápodo del "Lower Greenand" de Inglaterra, abundante en el Cretáceo nororiental Ibérico, p. 29-49: In, 1er. Symposium sobre el Cretácico de la Cordillera Ibérica, 257 p, Cuenca, España.

Via, L., 1988, Els decàpodes: In, Història Natural dels Països Catalans. 15 (Registre fòssil), 343-352.

Vilanova, J., 1863, Ensayo de descripción geognóstica de la provincia de Teruel en sus relaciones con la agricultura de la misma: Junta general de Estadística, Madrid. 312 p.

Woods, H., 1925-31, A monograph of the fossil macrurous Crustacea of England. Parts II-VII: Palaentographical Society, Monograph (parts $357,359,362,365,369,377,380), 122$ p.

Woodward, H., 1868, Fourth report on the structure and classification of the fossil Crustacea: Report of the meeting of the British Association for the Advancement of Science, 72-75.

Woodward, H., 1900, Further notes on podophthalmous crustaceans from the Upper Cretaceous formation of British Columbia. Geological Magazine, new series, 7, 432-435.

Manuscript received: September 21, 2007

Corrected manuscript recieved: October 18, 2007

Manuscript accepted: November 20, 2007 